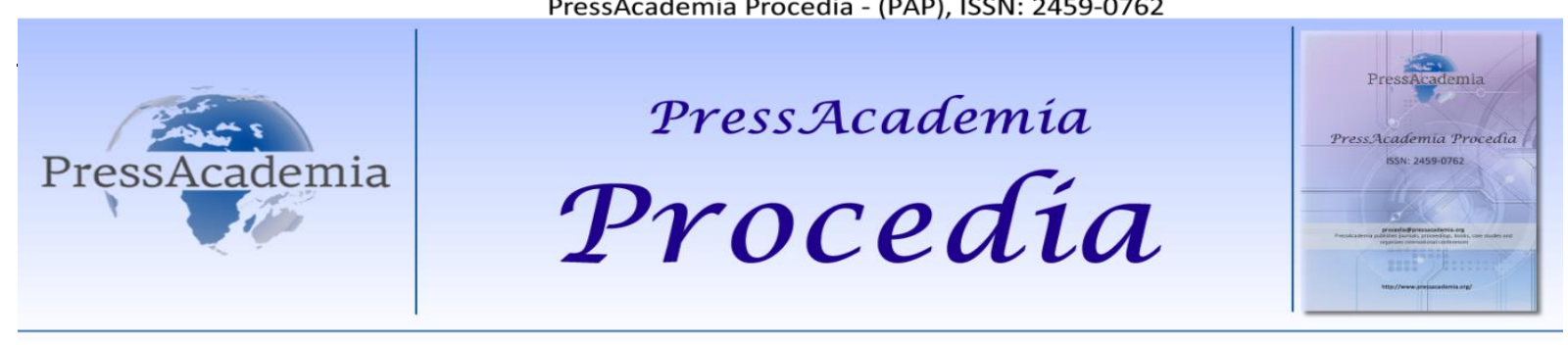

Global Business Research Congress (GBRC), May 24-25, 2017, Istanbul, Turkey.

\title{
IDENTIFICATION OF KEY PERFORMANCE INDICATORS OF AUDITOR'S REPORTS: EVIDENCE FROM BORSA ISTANBUL (BIST)
}

\section{DOI: $10.17261 /$ Pressacademia.2017.665 \\ PAP-GBRC-V.3-2017(92)-p.854-859}

\author{
Burcu Adiloglu ${ }^{1}$, Bengü Vuran ${ }^{2}$ \\ ${ }^{1}$ Istanbul University, Avcılar Campus, Faculty of Business Administration, Accounting Department, adiloglu@istanbul.edu.tr \\ ${ }^{2}$ Istanbul University, Avcılar Campus, Faculty of Business Administration, Finance Department, benguv@istanbul.edu.tr
}

\section{To cite this document}

Adiloglu, B. and B.Vuran, (2017).Identification of key performance indicators of auditor's report: evidence from Borsa Istanbul.

PressAcademia Procedia (PAP), V.3, p.854-859.

Permemant link to this document: http://doi.org/10.17261/Pressacademia.2017.665

Copyright: Published by PressAcademia and limited licenced re-use rights only.

\begin{abstract}
According to International Standards on Auditing (IAS) 700 -Forming an Opinion and Reporting on Financial Statements-the objectives of the auditor are to form an opinion on the financial statements based on an evaluation of the conclusions drawn from the audit evidence obtained and to express clearly that opinion through a written report. In the final step of audit process the auditor shall form an opinion on whether the financial statements are prepared, in all material respects, in accordance with the applicable financial reporting framework. The auditor shall modify the opinion in the auditor's report when: the audit or concludes that, based on the audit evidence obtained, the financial statements as a whole are not free from material misstatement. This study empirically examines distinctive financial indicators of qualified auditor's reports in Turkey to see whether there is a relationship between financial indicators and qualifications of an auditor's report. The aim of the paper is to analyze the qualified auditor's reports of Borsa Istanbul nonfinancial companies for the year 2016 and to show the circumstances in the company's financial position and performance that causes the qualifications by using key performance indicators (accounting ratios).
\end{abstract}

Key Words: Audit report, key performance indicators, Borsa Istanbul (BIST), Turkey.

JEL Code: M42, M41, G30

\section{INTRODUCTION}

Auditing is the accumulation and evaluation of evidence about information to determine and report on the degree of correspondence between the information and established criteria. Auditing should be done by a competent, independent person. (Arens et al., 2012) Audit address the assertions that the assets listed in the balance sheet really exist, that the company has title to the assets, and that the valuations assigned to the assets have been established in conformity with International Financial Reporting Standards. Evidence will be gathered to show that the balance sheet contains all the liabilities of companies. It will also gathered evidence about the income statement, cash flow statement and statement of owner's equity.

According to International Standards on Auditing (IAS) 700 -Forming an Opinion and Reporting on Financial Statements-the objectives of the auditor are to form an opinion on the financial statements based on an evaluation of the conclusions drawn from the audit evidence obtained and to express clearly that opinion through a written report. The auditor shall evaluate whether the financial statements are prepared, in all material respects, in accordance with the requirements of the applicable financial reporting framework. This evaluation shall include consideration of the qualitative aspects of the entity's accounting practices, including indicators of possible bias in management's judgments. 
The auditor shall evaluate whether, in view of the requirements of the applicable financial reporting framework:

(a) The financial statements adequately disclose the significant accounting policies selected and applied;

(b) The accounting policies selected and applied are consistent with the applicable financial reporting framework and are appropriate;

(c) The accounting estimates made by management are reasonable;

(d) The information presented in the financial statements is relevant, reliable, comparable, and understandable;

(e) The financial statements provide adequate disclosures to enable the intended users to understand the effect of material transactions and events on the information conveyed in the financial statements; and

(f) The terminology used in the financial statements, including the title of each financial statement, is appropriate.

According to International Standard on Auditing (ISA) 705 Modifications To The Opinion In The Independent Auditor's Report - the auditor concludes that a modification to the auditor's opinion on the financial statements is necessary.

International Standards on Auditing (IAS) 705 establishes three types of modified opinions, namely, a qualified opinion, adverse opinion, and a disclaimer of opinion.

The decision regarding which type of modified opinion is appropriate depends upon:

(a) The nature of the matter giving rise to the modification, that is, whether the financial statements are materially misstated or, in the case of an inability to obtain sufficient appropriate audit evidence, may be materially misstated; and

(b) The auditor's judgment about the pervasiveness of the effects or possible effects of the matter on the financial statements.

This study empirically examines distinctive financial indicators of qualified auditor's reports in Turkey to see whether there is a relationship between financial indicators and qualifications of an auditor's report.

The general purpose of the present study is to analyze the qualified auditor's reports of Borsa Istanbul nonfinancial companies for the year 2016 and to show the circumstances in the company's financial position and performance that causes the qualifications by using key performance indicators (accounting ratios).

The paper is organized as follows: In section II, a review of literature is presented. Section III explains the research methodology and section IV gives the results and in section $\mathrm{V}$ conclusion of the study is given.

\section{LITERATURE REVIEW}

A large number of studies have examined the modified audit reports and financial statement information. Some of them are given in this section.

Dopouch et al. (1987) developed a probit model to investigate the extent to which models based on financial and market variables predict auditors' decisions to issue a qualified audit report. Their results showed that the most significant variables in predicting qualifications are current year loss, the industry rate of return and the change in the ratio of total liabilities to total assets.

Keasey et al. (1988) used a logistic regression approach based on 12 financial and non-financial independent variables to explain audit qualifications for small companies. They showed that the likelihood that a company receives a qualified audit report increases when: the auditor is a large accounting firm; the number of directors is small; there are few non-director shareholders; the auditee has raised a secured loan; and there is a long time lag between the financial year-end and the audit report date.

Bell \&Tabor,(1991) examines the usefulness of financial statement and other data for modeling the auditor's decision process leading to the modification of audit reports for uncertainties. The auditor faces increased responsibility to evaluate and report on uncertainty about a client's continued existence under SAS No. 58 and SAS No. 59.

Chen and Church (1992) note that auditors can use the results of empirical models to plan specific auditing procedures that can be applied to achieve an acceptable level of audit risk. These models can also be used as a quality control tool in the review or final stage of an engagement and for contingency analyses on how changes in specific variables could add or detract from the probability of obtaining a qualified opinion.

Laitinen and Laitinen (1998) develops a logistic model based on financial statement information to identify qualified audit reports. The empirical data are retrieved from audit reports from thirty-seven publicly-traded companies (HeSE) in the 
years 1992, 1993 and 1994, They uses logistic regression analysis based on 17 financial and nonfinancial variables to explain qualifications in large companies in Finland. Their results shows that the likelihood of receiving a qualified audit report is higher with low growth rate, low equity/total assets, and small number of employees.

Spathis (2003) applied logistic and OLS regression models on data to assess the effect of firm litigation and financial metrics on audit qualifications. It is found that audit qualification decision was positively associated with financial information such as financial distress and with non-financial information such as firm litigation.

Caramanis \& Spathis (2006) tests the extent to which combinations of financial information with non-financial variables, such as audit fees and type of audit firm, can be used in predicting qualified and unqualified audit reports. The data were taken from a sample of 185 Greek companies listed at the Athens stock exchange and were analyzed using logistic and OLS regression models. It is found that audit fees and the type of audit firm (Big five vs non-Big five) do not affect auditors' propensity to qualify their opinions. Instead, the occurrence of audit qualifications is associated with financial metrics such as operating margin to total assets and the current ratio. The model developed was successful in classifying 90 per cent of the total sample.

Gaganis et al., 2007; considers the well known disadvantages of artificial neural network, we propose the application of probabilistic neural networks (PNNs) that combine the computational power and flexibility of ANNs, while managing to retain simplicity and transparency. The sample consists of 264 financial statements that received a qualified audit opinion over the period 1997-2004 and 3069 unqualified ones, from 881 firms listed on the London Stock Exchange. The results demonstrate the high explanatory power of the PNN Model in explaining qualifications in audit reports. The model is also found to outperform traditional ANN models, as well as logistic regression.

Zdolsek et al 2013 studies the qualification of auditors' reports in relation to the circumstances in the company's economic situation that lead to the qualification. Qualifications have been analyzed on a sample of 293 large Slovenian companies. The results reveal that companies with qualified auditors' reports have high indebtedness, low liquidity, low efficiency and poor profitability in comparison with companies with unqualified auditors' reports.

\section{DATA AND METHODOLOGY}

This paper investigates which key performance indicator variables predict auditors' decisions to issue unqualified or modified (a qualified opinion, adverse opinion, and a disclaimer of opinion) audit reports for nonfinancial companies listed in Borsa Istanbul for the year 2016. The sample is composed of 263 firms with 240 firms with unqualified and 21 firms with qualified and 2 firms with adverse audit opinion. This distribution is also shown in Table 2 and Figure 1. Financial performance variables are gathered from finnet database (www.finnet.gen.tr). Logistic regression analysis is developed with the dependent variable indicating whether the firm received an unqualified opinion or not and the independent variables representing publicly available financial and market data. The variables used in the analysis are shown in Table 1.

Table 1: Variables Used in the Analysis

\begin{tabular}{|l|l|l|}
\hline Y & Audit Opinion & (Unqualified Opinion: 1, modified: qualified or adverse opinion: 0) \\
\hline $\mathbf{X 1}$ & BIG 5 & (If the Audit Company is in BIG 5 1, otherwise 0) \\
\hline $\mathbf{X 2}$ & Current Ratio & Current Assets/Current Liabilities \\
\hline $\mathbf{X 3}$ & Return on Asset & Earnings Before Interest and Taxes / Total Assets \\
\hline $\mathbf{X} 4$ & Return on Equity & Net Profit After Taxes / Total Equity \\
\hline X5 & Debt Ratio & Total Debt / Total Assets \\
\hline X6 & Net Profit Margin & Net Profit After Taxes / Sales \\
\hline X7 & Price / Cash Flow & Market Price per share / Cash Flow \\
\hline X8 & Times Interest Earned & EBITDA / Interest Expense \\
\hline
\end{tabular}

Logistic regression analysis is conducted by SPSS 20 program. To eliminate the multicollinearity between the financial ratios and select the best set of explanatory variables forward conditional model is applied. The empirical results are explained in the next section. 
Table 2: Distribution of Audit Reports

\begin{tabular}{lc}
\hline Types of opinion & Number of Audit reports \\
\hline Unqualified audit opinion & 240 \\
Qualified audit opinion & 21 \\
Adverse audit opinion & 2 \\
Disclaimer of opinion & 0 \\
\hline Total & 263 \\
\hline
\end{tabular}

Figure 1: Distribution of Audit Reports

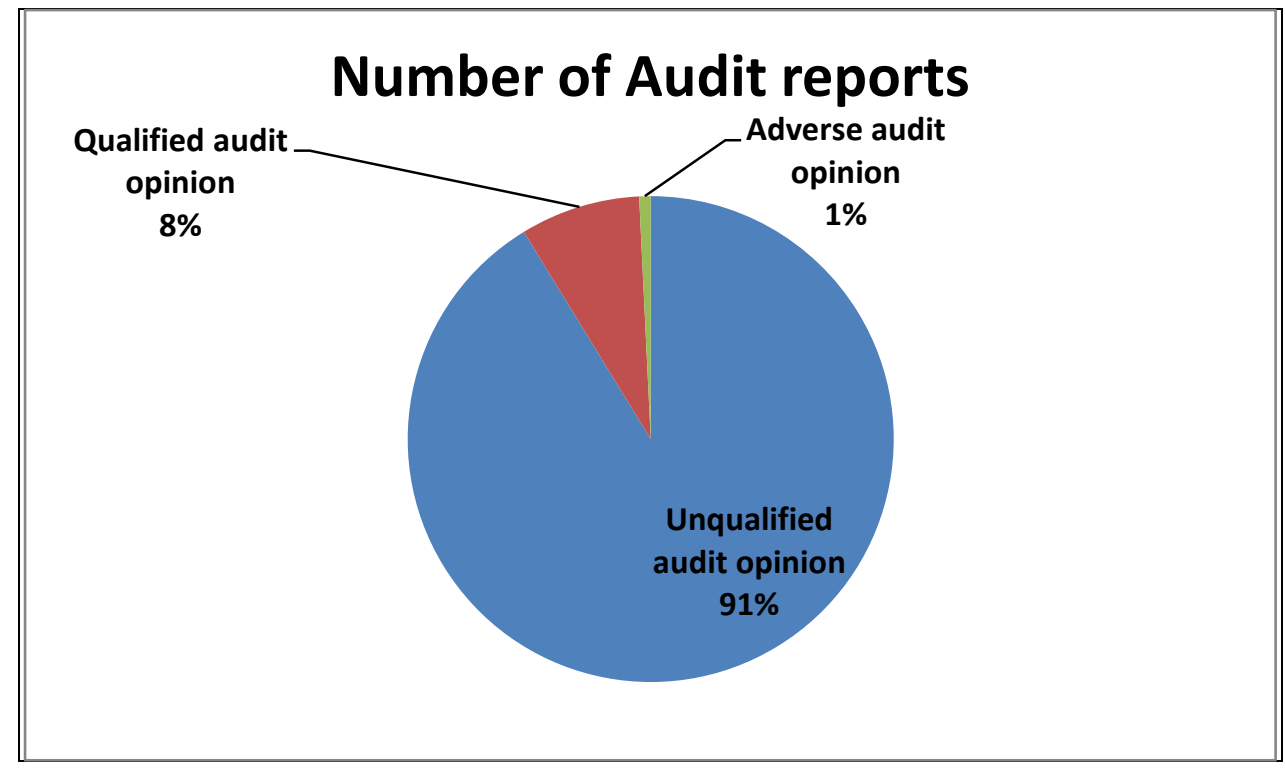

\section{RESULTS}

Before the estimation process begins, Hosmer and Lemeshow test is used to measure the overall fit of the model. This statistical test measures the correspondence of the actual and the predicted values of the dependent variable. The null and alternative hypotheses for assessing the overall model fit are as follows:

$\mathrm{H}_{0}$ : The hypothesized model fits the data.

$\mathrm{H}_{1}$ : The hypothesized model does not fit the data.

The Hosmer Lemeshow tests the null hypothesis that predictions made by the model fit perfectly with observed group memberships. A nonsignificant chi-square indicates that the data fit the model well. ( $p=.114>.05)$. Table 3 gives Hosmer and Lemeshow test results.

Table 3: Hosmer and Lemeshow Test Results

\begin{tabular}{|c|c|c|}
\hline Chi-square & df & Sig. \\
\hline 12,943 & 8 &, 114 \\
\hline
\end{tabular}

Table 4 displays the "Omnibus Tests of Model Coefficients" which performs the overall test of the model. The omnibus test is a likelihood-ratio chi-square test of the current model versus the null (in this case, intercept) model. The significance value of less than $5 \%$ indicates that the current model outperforms the null model. 
Table 4: OmnibusTests of Model Coefficients

\begin{tabular}{|c|c|c|c|}
\hline Block & 29,304 & 4 &, 000 \\
\hline Model & 29,304 & 4 &, 000 \\
\hline
\end{tabular}

The $\mathrm{R}^{2}$ values tell approximately how much variation in the outcome is explained by the model. As it is shown in Table 5 , Nagelkerke'sR ${ }^{2}$ which suggests that the model explains roughly $23,6 \%$ of the variation in the outcome.

Table 5: Model Summary

\begin{tabular}{|c|c|c|}
\hline $\mathbf{- 2}$ Loglikelihood & Cox\&Snell R Square & Nagelkerke R Square \\
\hline 126,710 &, 105 &, 236 \\
\hline
\end{tabular}

Table 6 provides the regression coefficient (B), the Wald statistic (to test the statistical significance) and the all important Odds Ratio (Exp (B)) for each variable category. As it is displayed in the table BIG5, ROA, ROE and EBITDA/ INT variables are found to be statistically significant at $5 \%$.

Table 6: Logistic Regression Results (Variables in the Equation )

\begin{tabular}{|c|c|c|c|c|c|c|}
\hline & B & S.E. & Wald & df & Sig. & Exp(B) \\
\hline BIG5 & $-1,316$ & 0,545 & 5,837 & 1 & 0,016 & 0,268 \\
\hline ROA & $-0,079$ & 0,036 & 4,734 & 1 & 0,030 & 0,924 \\
\hline ROE & 0,050 & 0,014 & 13,177 & 1 & 0,000 & 1,052 \\
\hline EBITDA_INT & 0,061 & 0,026 & 5,473 & 1 & 0,019 & 1,063 \\
\hline Constant & 3,417 & 0,495 & 47,582 & 1 & 0,000 & 30,475 \\
\hline
\end{tabular}

According to Table 6 , the regression function can be written as:

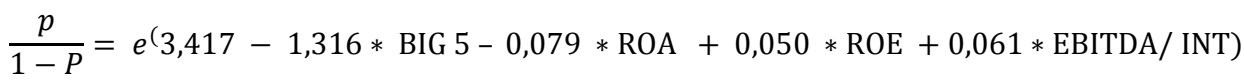

Table 7 presents the classification results which displays that the estimated model's accurate prediction is $92.4 \%$. Number of misclassification of unqualified report is 1 out of 240 and 19 out of 23 qualified and other reports. And the high predictive accuracy of the model stems from the fact that the number of observations correctly classified is very high.

Table 7: ClassificationTable ${ }^{a}$

\begin{tabular}{|c|c|c|c|c|}
\hline \multicolumn{2}{|l|}{ Observed } & \multicolumn{3}{|c|}{ Predicted } \\
\hline & & \multicolumn{2}{|c|}{ Report Type } & \multirow[t]{2}{*}{ Percentage Correct } \\
\hline & & 0 & 1 & \\
\hline \multirow[t]{2}{*}{ Report Type } & 0 & 4 & 19 & 17,4 \\
\hline & 1 & 1 & 239 & 99,6 \\
\hline \multicolumn{4}{|c|}{ Overall Percentage } & 92,4 \\
\hline
\end{tabular}

a. The cut value is, 500

\section{CONCLUSION}

An auditor determines whether the financial statements of an entity are presented fairly in all material respects and in accordance with accounting standards by reviewing the underlying information and processes that went into preparing the financial statements. In unqualified audit report the auditor concludes that the financial statements of a given entity are presented fairly, in all material respects, in accordance with generally accepted accounting principles. Modified opinions; qualified opinion, an adverse opinion, or a disclaimer of opinion occur when the auditor expresses different opinions on various aspects of the financial statements.

The aim of the study is to analyze the qualified auditor's reports of Turkish nonfinancial companies listed in Borsa Istanbul for the year 2016 and to show the circumstances in the company's financial situation that led to the qualification. A logistic model that considers various company ratios, the majority of these are financial ratios, is developed to explain the qualification of the auditors' reports. And the predictive accuracy of the estimated model is evaluated. 
Results of the analysis show that the qualification of an audit report is mainly associated with return on asset, return on equity, times interest earned ratio and whether the audit firm is classified as BIG 5 or not. The estimated model distinguishes between unqualified and other opinions for nonfinancial companies with a $92.4 \%$ classification accuracy.

Although the overall accuracy of the logistic regression model is very high, regarding the population characteristics there is an increased risk that the study results might be biased. The fact that the study is done for a single period and the number of companies (240 out of 263) which have unqualified audit opinions is very high might lead the results to be biased. And 19 out of 23 companies with qualified audit report are misclassified by the estimated model. This result also leads to a conclusion that other issues rather than the deterioration in financial ratios might induce the companies to have an audit report other than unqualified.

A possible further research can be done on a balanced sample of companies from other countries for larger period.

\section{REFERENCES}

Arens, A. A., Elder, R. J., \& Mark, B. (2012). Auditing and assurance services: an integrated approach. Boston: Prentice Hall.

Bell, T. B., \& Tabor, R. H. (1991). Empirical analysis of audit uncertainty qualifications. Journal of Accounting Research, 29, p.350-370.

Caramanis, C., Spathis, C., (2006) "Auditee and audit firm characteristics as determinants of audit qualifications: Evidence from the Athens stock exchange", Managerial Auditing Journal, Vol. 21 Issue: 9, p.905-920

Chen, K. andChurch, B. (1992), "Default on debt obligations and the issuance of going concern opinions", Auditing: A Journal of Practice and Theory, p. 30-49, Fall.

Dopouch, N., Holthausen, R. and Leftwich, R. (1987), "Predicting audit qualifications with financial and market variables", The Accounting Review, Vol. 62 No. 3, p. 431-54.

Gaganis, C., Pasiouras, F., \& Doumpos, M. (2007). Probabilistic neural networks for the identification of qualified audit opinions. Expert Systems with Applications, 32, p.114-124.

International Standards on Auditing (IAS) 700 -Forming an Opinion and Reporting on Financial Statements International Standard on Auditing (ISA) 705 Modifications To The Opinion In The Independent Auditor's Report

Keasey, K., Watson, R. and Wynarzcyk, P. (1988), "The small company audit qualification: a preliminary investigation", Accounting \& Business Research, Vol. 18 No. 72, p. 323-33.

Laitinen, E. K., \&Laitinen, T. (1998). Qualified audit reports in Finland: Evidence from large companies. European Accounting Review, 7, p. 639-653.

Spathis, C. (2003), "Audit qualification, firm litigation, and financial information: an empirical analysis in Greece", International Journal of Auditing, Vol. 7 No. 1, p. 71-85

Zdolšek, D., Jagrič, T., MarjanOdar,M.,(2015) . "Identification of auditor's report qualifications: an empirical analysis for Slovenia." Ekonomskaistraživanja 28.1, p. 994-1005. 